\title{
Kultura szkoły w narracji dziecka. Pomiędzy szansą a zagrożeniem dla rozwoju dziecka-ucznia
}

\begin{abstract}
Streszczenie
W artykule zwracam uwagę na elementy kultury szkoły, które są obecne w narracji dziecka-ucznia, osadzając swoje rozważania w psychokulturowym podejściu do edukacji oraz Goffmanowskim modelu instytucji totalnych.

„Zderzenie świata” dziecka, kreowanego przez kulturę środowiska rodzinnego z kulturą szkoły niesie za sobą wiele napięć i imperatywów stałego rekonstruowania znaczeń do tej pory (nie)obecnych w jego biograficznych doświadczeniach. Analiza oraz interpretacja wywiadu narracyjnego dziecka w podejściu konstruktywistycznym umożliwiła zgromadzenie wiedzy na temat wzorców zachowań, zakazów, nakazów, oczekiwań oraz wartości, które kultura szkoły w sposób jawny lub ukryty narzuca dziecku, socjalizując go do roli ucznia. Podjęte aspekty kulturowe w narracji dziecka ukazują, jakie elementy kulturowego świata szkoły mogą stanowić szansę i zagrożenia dla rozwoju jego tożsamości oraz osobowości dla poczucia sprawstwa oraz wartości.
\end{abstract}

\section{Słowa kluczowe:}

kultura szkoły, totalna kultura szkoły, dziecko, uczeń, socjalizacja, wychowanie, tożsamość

1 Kinga Konieczny-Pizoń, Wydział Nauk Społecznych, Uniwersytet Śląski w Katowicach, Polska, e-mail: k_konieczny@op.pl, ORCID ID: https://orcid.org/0000-0001-6203-8651. 


\begin{abstract}
In the article, I focus on the elements of school's culture, which is present in the narrative of the child's student, embedding my reflections in the psychocultural approach to education (J.S. Bruner) and the Goffman's model of total institutions.

The collision of the child's world, created by the culture of the family environment with the culture of the school, brings with it many tensions and imperatives for the constant reconstruction of meanings so far (un) present in his biographical experience. The analysis and interpretation of the child's narrative interview in a constructivist approach has allowed to gather knowledge about patterns of behavior, prohibitions, precepts, expectations and values that the school culture overtly or covertly imposes on the child, socializing him/her into the role of a student. The cultural aspects taken up in the child's narrative show what elements of the school's cultural world represent opportunities and threats for the development of his or her identity and personality towards a sense of causality and values.
\end{abstract}

\title{
Keywords:
}

school culture, total school culture, child, student, socialization, upbringing, identity

Nic nie jest wolne od kultury (Bruner, 2006, s. 4, 16, 81), człowiek wytwarza kulturę, jest „zaprogramowany umysłowo” już w pierwotnym środowisku rodzinnym, które w późniejszych etapach zostaje zmienione na szkołę i inne środowiska pozaszkolne (Hofstede, Hofstede, 2007, s. 17, 378). Szkoła to miejsce, w którym realizacja działań edukacyjnych niesie za sobą konieczność wyposażenia dziecka w pewien zestaw kulturowych narzędzi (Hofstede, Hofstede, 2007, s. 38, 230-231), umożliwiających wytwarzanie znaczeń oraz interpretację świata i siebie. Kultura (świat) ${ }^{2}$ szkoły stanowi ogromne wyzwanie dla dziecka, który dźwiga również własny, rodzinny kulturowy bagaż. Dziecko-uczeń nie tylko staje się badaczem-obserwatorem, monitorującym to, co dzieje się w instytucji w odniesieniu do elementów kulturowego świata szkoły, ale i uczestnikiem danej kultury, który posiada możliwość głębszego poznania, zrozumienia oraz finalnie zrekonstruowania jej założeń (por. Tuohy, 2002, s. 25).

${ }^{2}$ Kulturę w niniejszym opracowaniu traktuję jako synonim świata, w którym wzrasta i funkcjonuje człowiek. Kultura jest również systemem, aparatem adaptacyjnym jednostki, odzwierciedlającym się w materialnym, behawioralnym, aksjologicznym i psychologicznym świecie człowieka (por. Nowicka, 2009, s. 52-57). 
Psychokulturowe podejście do edukacji opracowane przez Jerome’a S. Brunera (2006) stanowiło dla mnie inspirację do spojrzenia na kulturę jako konstrukt odzwierciedlający się w życiu i myśleniu człowieka, stale renegocjowany, tworzony przez jego osobiste doświadczenie i relacje z innymi oraz światem (Bruner, 2006, s. 139). Założenia te stały się również bazą do dokonania rekonstrukcji pojęć: kultury szkoły i totalnej kultury szkoły oraz eksplikacji obrazu szkoły w percepcji dziesięcioletniego dziecka. W niniejszym opracowaniu koncentruję się na poszukiwaniu odpowiedzi na następujące pytania: w jaki sposób dziecko postrzega szkołę?

\section{WPROWADZENIE}

Rozważania dotyczące szkoły w nawiązaniu do psychokulturowej koncepcji J.S. Brunera pozwalają ją analizować jako „wspólne miejsce”, osadzone w charakterystycznej przestrzeni kulturowej, tworzonej przez ludzi i przedmioty (Bruner, 2006, s. 3, 10, 119-120). Kultura szkoły natomiast jest dynamicznym tworem, stale się konstruującym, specyficznym dla konkretnej instytucji, wymagającym poznania, zrozumienia i aktywnego uczestnictwa. To zespół pewnych szans, przywilejów (korzyści), praw, przyjętych systemów wartości, ale i pojawiającej się struktury władzy. Nie jest wypadkową indywidualnych konstruujących się kultur zbiorowości - powstaje na granicy napięcia pomiędzy tym, czego oczekuje społeczeństwo (szkoła), a tym, co jest potrzebne uczniowi (Bruner, 2006, s. 31, 100). Jest zatem z jednej strony nadorganiczna, ponieważ konstruuje się w symbolicznym systemie, który dostarcza poszczególnym członkom instytucji ${ }^{3}$ pewnych kategorii umożliwiających organizację i tworzenie wymiarów jej funkcjonowania (Bruner, 2006, s. 16, 235). Z drugiej ukazuje indywidualne mikroświaty jednostek, które wytwarzają je w wyniku dyskursów, negocjacji, współpracy (Bruner, 2006, s. 99-112; Filipiak, 2011, s. 100-102) i w relacji do zastanego kulturowego świata. Kultura szkoły w Brunerowskim rozumieniu oferuje uczniom nowe możliwości, szanse na rozwój, kreowanie tożsamości poprzez możliwość wymiany indywidualnych zasobów (talenty, wiedza, przekonania) na symboliczne oznaki prestiżu oraz statusu. Pozwala to dziecku na doświadczanie oraz (z)rozumienie swojego sprawstwa i poczucia kontroli (Bruner, 2006, s. 4, 50, 119-120). Jej instytucjonalny charakter jest również źródłem władzy, nadając poszczególnym osobom pozycje, zadania, prawa (Bruner, 2006, s. 50).

3 Za członków instytucji (szkoły) przyjmuję uczniów, nauczycieli, dyrekcję, kadrę niepedagogicznych pracowników oraz rodziców. 
Dziecko postrzegane jest tutaj jako „podmiot poznający i uczący się”, wnoszący w przestrzeń szkoły swoje indywidualne interpretacje świata, będąc jednocześnie stymulowanym przez kulturę szkoły (Bruner, 2006, s. 82-95). W relacji z kulturą dziecko nie powiela oferowanych znaczeń w sposób jednoznaczny, interakcje natomiast z drugą osobą i instytucją pozwalają mu na konstruowanie własnych modeli świata, które odnosi do interpretacji znanych mu doświadczeń, osadzonych w jego biografii i kulturowych wzorcach rodzinnego domu (Bruner, 2006, s. 31, 32; Wygotski, 1971, s. 49). Poznanie charakteru kultury szkoły, jak również jej zmiana zachodzi w drodze narracji, która także umożliwia konstruowanie tożsamości ucznia i odnalezienie się w kulturowych labiryntach (Bruner, 2006, s. 67-68).

Szkoła jest instytucją kulturową (Illich, 2010), w której nierzadko również dokonuje się polityczne odbicie „klas panujących” narzucających określoną kulturę i typ wiedzy. Owo narzucanie konstatujące się w przemocowym sposobie reprodukcji kultury szkoły odzwierciedla się nie tylko w rytualizacji zachowań związanych z podporządkowaniem się określonym normom (Illich, 2010, s. 60), ale i w dyscyplinarnym charakterze władzy (Foucault, 2009). Zestawienie kategorii przymusu, władzy, przemocy w kontekście instytucji (szkoły) nawiązuje do Goffmanowskiego modelu instytucji totalnych (Goffman, 2011) i w odniesieniu do podejmowania dialogu o kulturze szkoły wymaga zrekonstruowania pojęcia „kultury totalnej szkoły”.

Goffmanowski model kultury instytucji totalnej odzwierciedla się w: sformalizowanej rzeczywistości (system norm, wzorców postępowania, wartości) (Goffman, 2011, s. 98-99, 110-11), reprezentacjach myślowych mieszkańców oraz pracowników (przekonaniach) (Goffman, 2011, s. 22-24, 73, 85, 90, 92-93, 116), (pod)kulturze „drugiego życia” (Goffman, 2011, s. 162-165), konstruującej się wtórnie tożsamości pensjonariuszy (Goffman, 2011, s. 58). Kultura instytucji totalnej manifestuje zunifikowanie, zatarcie indywidualności (Goffman, 2011, s. 48-50) - nie podejmuje dialogu z dotychczasową biografią i tożsamością jednostki, widząc w niej zagrożenie dla instytucji czy systemu. Blokuje rozwinięcie tożsamości w kierunku jej decyzyjności i sprawstwa (Goffman, 2011, s. 23). W Goffmanowskim świecie to, co istotne, sprowadza się tworzenia nowego człowieka, który musi działać oraz myśleć w odniesieniu do ustalonych odgórnie norm (por. Goffman, 2011, s. 28, 79; Baranowska, 2008, s. 16-17).

Totalność kultury szkoły można zatem upatrywać w jej biurokratycznym stylu zarządzania, w którym nie tylko formalnie (w postaci przepisów, regulaminów), ale i w uczniowskiej narracji ujawniają się hierarchiczne struktury władzy. Obecny jest także binarny podział szkolnego świata na nauczycieli oraz uczniów ${ }^{4}$, przejawia-

${ }^{4}$ Analogie szkoły do instytucji totalnych akcentujących hierarchiczny podział wśród nauczycieli 
jących wobec siebie jawne lub ukryte stereotypy niechęci czy wrogości (Wagner, 2005, s. 37; Buliński 2012, s. 166). Dziecko-uczeń traktowane jest jako materiał poddawany zabiegom dyscyplinującym, odbierającym autonomię, których efektem może być pożądana politycznie pokorność i posłuszeństwo (Foucault, 2009, s. 131-155) lub piętnowany opór (McLaren, 2015; Babicka-Wirkus 2015; 2018).

Rytuały szkolne odgrywają ważną rolę w procesie wtórnej socjalizacji. Socjalizacja rozumiana jako „wrastanie w kulturę” (Miller, 1981, s. 55), świadczy o pewnej jakości funkcjonowania jednostki w kulturze i jej interakcjach. Dopełniana również przez wychowanie i odwrotnie, implikuje powstawanie napięć i konfliktów w wyniku ścierania się wewnętrznego świata człowieka (kultury ucznia) ze światem zewnętrznym (kulturą szkoły, poszczególnych nauczycieli), czego efektem jest tworząca się osobowość. Rytuały przyjmują rolę jednych z najskuteczniejszych narzędzi socjalizacji (Piwowarski, 1996, s. 203-204). Wprowadzają również w proces uspołeczniania, dzięki któremu uczeń wie, jak należy się zachowywać, co finalnie pozwoli mu na uczestnictwo w coraz bardziej skomplikowanych strukturach społecznych (por. Goffman, 2011, s. 45). Socjalizowanie (urabianie/modelowanie) dziecka w ucznia dokonuje się również przez ustanowione i realizowane normy, wartości, kreujące rzeczywistość szkolną oraz odnoszące się do: ograniczenia jego wolności, wygaszenia tożsamości budowanej na wzorcach kulturowych pierwotnego środowiska i dyscyplinowania.

Formalizacja systemu nakazów i zakazów, wyznaczających aprobowane zachowania uczniów, które są wzmacnianie lub wygaszane za pomocą kar, nagród i przywilejów w kulturze totalnej szkoły, będzie również odnosiła się do negowania rozwoju tożsamości ucznia w kierunku sprawstwa i poczucia kontroli (Foucault, 2009, s. 177-178). Przekonania uczniów dotyczące szkoły w perspektywie jej totalnej kultury 5 są/mogą być budowane o refleksje związane z niemożnością wykonywania działań i niedostępnością wartości, które były lub są częścią ich indywidualnego, kulturowego świata.

W perspektywie instytucjonalnej kultura totalna szkoły posługująca się przymusem, kontrolą, systemem zakazów i nakazów nie sprzyja przygotowaniu ucznia do podążania za zmianami społecznymi ${ }^{6}$, utwierdzając w przekonaniu o stałości

i uczniów można odnaleźć w publikacjach: Czarnecka, K., Zagółkowa, H. (1991). Słownik gwary uczniowskiej. Poznań: Kantor Wydawniczy SAWW, s. 244; Meighan, R. (1993). Socjologia edukacji. Toruń: Wydawnictwo Uniwersytetu Mikołaja Kopernika.

${ }^{5}$ Przekonania na temat instytucji, nauczycieli, poszczególnych uczniów powstają w oparciu o poprzednie doświadczenia, wiedzę, kulturę, a także na podstawie rozwiniętych systemów reprezentacji (enaktywne, symboliczne, ikoniczne) (Bruner 1978, s. 526-542).

${ }^{6}$ Nieprzygotowywanie uczniów do funkcjonowania w zmieniającej się kulturze, świecie, ak- 
i prawdziwości oraz dominacji narzuconej kultury, rozgrywającej się w szkole. Konstruuje się głównie wokół działań zmierzających do: unifikacji dzieci, sprawnego ich zarządzania, bez potrzeby akcentowania dziecięcych biografii. Perspektywa indywidualna, w której uczeń wytwarza znaczenia konstytuujące się na granicy spotkania dwóch kultur - własnej i instytucjonalnej - w odniesieniu do totalnej kultury szkoły odnosić się będzie do radzenia sobie z próbami (z)rozumienia otaczającego świata i badania (nie)możliwości prezentacji osobistej kultury poprzez postawy, odrębny język, stosowane strategie, zachowania (Wróblewski, 2014, s. 33).

\section{METODA $^{7}$}

O swobodną narrację, będącą, jak twierdził J.S. Bruner (2006, s. 67), „narzędziem umysłu, służącym do wytwarzania znaczeń”, dotyczącą szkołyº, poprosiłam dziesięcioletnią dziewczynkę, która w trakcie udzielanego wywiadu (listopad 2019) uczęszczała do czwartej klasy w jednej z bytomskich podstawówek. Niewątpliwie dla przebiegu rozmowy istotne było dla dziecka doświadczenie zmian zachodzących w trakcie przekraczania progu edukacyjnego i rozpoczęcia nauki w klasie czwartej. Przejście z klasy trzeciej do następnej pozwoliło na wystąpienie u dziecka napięcia w wyniku zderzenia znanej rzeczywistości (klas I-III) i sposobów jej rozumienia z nowym mikroświatem, pełnym nieznanych dotąd zwyczajów, norm, wartości, obowiązków i nauczycieli, reprezentujących różne style myślenia, działania, nauczania. Już samo wyjście z pierwotnego środowiska kulturowego (rodziny) do szkoły również jako instytucji kulturowej pociąga za sobą możliwość starcia się kultur i skonfrontowania dziecka z odmiennością wzorów zachowań oraz odniesień.

Spostrzeganie dziecka jako uczestnika i (współ)twórcę kultury szkoły implikuje imperatyw stałego rozpoznawania i (re)konstruowania siebie oraz otaczającego go świata. W niniejszym opracowaniu poszukuję odpowiedzi na pytanie o obraz

centującej nieustanną konieczność konstruowania, dyskutowania, tworzenia znaczeń w odniesieniu do kultury totalnej szkoły można uznać za symboliczną izolację od świata, który istnieje za murami szkoły.

7 Wywiad narracyjny jest częścią materiału badawczego zgromadzonego w ramach przygotowanej rozprawy doktorskiej dotyczącej postrzegania nauczycieli i szkoły przez dzieci z układu ryzyka, pt. Nauczyciele i szkoła w percepcji dzieci z układu ryzyka (na przykładzie wybranego miasta z Górnego Ślq̨ska), przygotowywanej pod kierunkiem naukowym dr hab. Anny Szafrańskiej, prof. UŚ.

8 Pytanie inspirujące, otwierające rozmowę brzmiało: „Proszę, opowiedz mi o Twojej szkole”. 
szkoły w percepcji dziecka, które w myśl konstruktywizmu jest: badaczem oraz specjalistą od doświadczenia, tworzenia, przeżywania i rozumienia (por. James, Jenks, i in., 1998; Lee, 2001). Wywiad został zanalizowany i zinterpretowany w podejściu konstruktywistycznym (Gibbs, 2015, s. 27-29). Strategia analizy tekstu wiązała się z kodowaniem rzeczowym wers po wersie (analiza strukturalna), gdzie nadawałam etykiety/nazwy poszczególnym kategoriom, używając języka rozmówczyni. Następnie porównywałam je ze sobą, akcentując wzajemne relacje i powiązania, a także stosowałam szersze (abstrakcyjne) kategorie pojęciowe (analiza kategorialna) (por. Konecki, 2000). Pozwoliło mi to na odnalezienie wzorca konceptualizacji (kultura szkoły) obecnego w poszczególnych fragmentach narracji, umożliwiającego wytłumaczenie danej sekwencji lub/i jej zmienności. Powstałe wyniki odniosłam do literatury przedmiotu, zgodnie z założeniami teorii ugruntowanej.

\section{WYNIKI BADAŃ}

Dziewczynka w momencie przeprowadzenia wywiadu była po trzecim miesiącu nauki w klasie czwartej i swoją narrację rozpoczęła od następującej wypowiedzi:

Lubię chodzić do szkoły, odkąd pojawiły się szafki. Na każdej przerwie chodzę do szafki i coś tam wyciągam i ozdabiam. Szafki pojawiły się od początku listopada, ale klucze dostaliśmy trzy tygodnie temu (...) Tam trzymam wszystko i jak mamy już kluczyki do szafek to możemy już [trzymać rzeczy - uzupeł. K. KP] (...) I kiedy mamy te szafki, to Marcel [brat - uzupeł. K. KP] pyta czy może coś zostawić, ale rzadko coś (D) ${ }^{9}$.

Z wypowiedzi dziecka wynika, że szkoła - przychodzenie do niej - może być wydarzeniem niosącym za sobą określony komponent emocjonalny. Szafka, która zostaje przydzielona dziewczynce, powoduje, iż szkoła zaczyna być dla dziecka atrakcyjna i wywołuje pozytywne odczucia. Staje się dla dziecka miejscem (zamykanym na klucz), w którym trzyma wszystko, i do którego się przywiązuje, pielęgnuje, czyni ją „swoją” oraz dogląda na każdej przerwie. Jest symbolicznym odzwierciedleniem prywatnego miejsca, do którego dziecko wraca na każdej przerwie, i w/przy którym bywa - „Czasami też w szafce siedzę. Nie w szafce,

9 Przyjęłam następujący zapis wywiadu: treści wypowiadane przez dziecko oznaczyłam symbolem (D), natomiast uzupełnienia, pytania badaczki opatrzyłam swoimi inicjałami (K.KP). 
ale przy szafce” (D). Można przypuszczać, iż to jedno z pierwszych doświadczeń i emocjonalnych reakcji na otrzymanie prawa do prywatności, pozwalającego dziecku na eksperymentowanie z oswajaniem oraz uczeniem się swojego miejsca w rozległej przestrzeni szkoły. Przyznanie przez instytucję prywatnej przestrzeni dziecku stanowi okazję do budowania tożsamości i uświadamiania ważnych dla dziecka wartości. Już samo miejsce w perspektywie antropologicznej, dzięki przypisywanym znaczeniom i symbolice, jest tożsamościotwórcze (Augé, 2010, s. 27-45). Pojawia się jednak pytanie o to, dlaczego właśnie dopiero przydzielenie prywatnego miejsca dziecku w przestrzeni szkoły spowodowało, że uczęszczanie do instytucji wiązało się z pozytywnym stanem emocjonalnym? W kolejnych wypowiedziach dziewczynka nawiązuje do trudności w dostosowaniu się do zmian, które obserwuje w odniesieniu do poprzednich doświadczeń z klas nauczania początkowego:

Od czwartej klasy trochę mi się nie podoba pani z polskiego. I musimy ciągle chodzić po szkole [w czwartej klasie - uzupeł. K. KP]. Za dużo chodzenia i trzeba ciągle to tornistry z tym nosić, a tak to dajemy np. jak wychodzimy z klasy to dajemy sobie pod tą. [salę - uzupeł. K. KP] nie musimy zabierać plecaków i tam mamy ciągle lekcje [odniesienie się do zajęć z klas I-III uzupeł. K. KP], a tak to musimy ciągle chodzić. Już wiem gdzie chodzić, ale czasami mam problemy z przyrodą, bo czasami mamy w bibliotece, raz mamy u pani w sali, raz mamy na dole na parterze. Ja idę za klasą, bo oni lepiej wiedzą. Mają plan (D).

Dziecko konfrontuje się w czwartej klasie ze zmianą w zakresie przymusu eksplorowania przestrzeni szkolnej celem poszukiwania sali, w której będą odbywały się lekcje, a także koniecznością noszenia za sobą tornistrów. Poprzednie doświadczenie uczenia się w jednej klasie jest jeszcze obecne i żywe w świadomości dziecka, ponieważ opowiadając o nim, miesza ze sobą czas przeszły z teraźniejszością. Wydaje się na granicy pomiędzy tym, co jest (po) znane (własnym światem) a tym, co nieznane (społecznym światem szkoły). Dziecko spotyka się z nową sytuacją, w której szkoła odgórnie narzuca odmienne od dotychczasowych sposoby zachowania się uczniów i wyposaża ich od tej pory w stały atrybut ucznia - tornister. Spotykanie się z innymi normami powoduje, iż dziewczynka stara się poszukiwać rozwiązań umożliwiających radzenie sobie w nowym świecie szkoły i przystosować się do wymaganych przez instytucję działań. Pojawiające się nowe wzorce zachowań, normy, będące odzwierciedleniem kultury tworzonej przez szkołę, a także wewnętrzne przeżywanie kontaktów z nową nauczycielką można lepiej zrozumieć, wykorzystując 
rozważania J.S. Brunera dotyczące kultury (Bruner, 2006, s. 126, 139). Kultura jest postrzegana przez pryzmat otaczającej jednostki rzeczywistości - to życie i myślenie, które stale jest (re)konstruowane w relacji do dotychczasowych doświadczeń, wiedzy, emocji, jak i interakcji. Niesie ona za sobą przystosowawczą funkcję umożliwiającą wzrastanie i działanie w kulturze danego społeczeństwa, ale również budowanie tożsamości człowieka (Bruner, 2006, s. 9, 210). Dziecko jest tworzone przez kulturę (świat), w której wzrasta, i na którą składa się określony świat wartości. To, z czym dziecko będzie konfrontowało się w szkole (z jakim światem - jaką kulturą), będzie odzwierciedlać się w jego osobowości oraz w sposobach myślenia, działania, przeżywania. Te z kolei przekładają się na przystosowanie do kultury (świata), której świadomie jeszcze nie rozumie, ale odczuwa i przyswaja (por. Miller, 1981, s. 120-122, 184). Poznawanie szkoły odbywa się poprzez kulturowe soczewki dziecka tworzone na bazie jego uprzednich doświadczeń (przeszłości), jak i w wyniku aktualnych interakcji z instytucją. Bycie w relacji z kulturą można również za Romaną Miller odnieść do procesu socjalizacji i wychowania (Miller, 1981). Socjalizacja rozumiana jest przez nią jako proces spontanicznego wzrastania w kulturę, finalnie sprowadzającą się do zaangażowanego i aktywnego bycia w świecie, nawiązywania relacji w oparciu o wyznawane przez partnerów interakcji wartości. Wychowanie natomiast jest uzupełnieniem socjalizacji - dostarczeniem umiejętności nawiązywania relacji z światem (kulturą), jak i wiedzy umożliwiającej zrozumienie świata, w którym funkcjonuje (Miller, 1981, s. 55, 114, 122). Przy czym wychowanie jest zorganizowanym i celowym procesem, wynikającym z potrzeb określonej grupy społecznej (Miller, 1981, s. 49). Kultura (świat) szkoły przez dziecko postrzegane jest $\mathrm{w}$ fragmencie narracji przez pryzmat przymusowego realizowania nowych wzorców zachowań oraz norm, których jeszcze nie rozumie, ale stara się je wypełniać na poziomie działania. Dziecko nie może oficjalnie polemizować z odgórnym zaleceniem - wydawać by się mogło, że przekroczenie progu edukacyjnego jest stopniowym wprowadzeniem dziecka w rolę ucznia. Tak jak w kulturze totalnej instytucji jednostka zostaje zapoznana z oficjalnym światem (kulturą) pełnym norm, wzorców zachowania, musi nauczyć się myślenia, czucia w zgodzie z celem instytucji, aż do momentu wtórnej socjalizacji (por. Goffman, 2011, s. 139-141), tak dziecko oswojone z wzorcami zachowania przygotowuje się do radzenia w fazie stopniowego przystosowania się do sytuacji („(...) Ja idę za klasą, bo oni lepiej wiedzą. Mają plan (D)).

Pojawia się zatem pytanie o to, do czego szkoła przygotowuje - socjalizuje i wychowuje - ucznia? W kolejnej wypowiedzi dziecko porusza kwestię wzorów zachowania w oczekiwaniu na nauczyciela oraz na lekcji: 
I musimy ciągle stać, ciągle pod tą klasą. I jak widzę, że pani [nauczycielka - uzupeł. K. KP] idzie, to my szybko wbiegamy na górę i się ustawiamy. W parach [stoimy - uzupeł. K. KP], jak siedzimy, bo tam są podwójne ławki: na przykład ja z K. i siedzę, i muszę z nią być w parze (D).

Zachowanie dzieci jest sprzężone z działaniem nauczyciela. Dzieci muszą na niego stale czekać w odpowiednim porządku, który również funkcjonuje w klasie szkolnej. Z wypowiedzi dziewczynki wynika, iż szkolny świat (kultura) jest przewidywalny w zakresie sformalizowanych sposobów postępowania - dziecko wie, jaki rodzaj działania jest oczekiwany przez szkołę oraz w jakiej sekwencji. Standaryzacja i powtarzalność narzuconych wzorców zachowań, które występują w narracji dziecka, są istotnymi cechami specyficznych dla danej kultury rytuałów (Eller, 2012, s. 353). Tworzone są po to, aby przestrzegać ładu i porządku oraz unikać występowania sytuacji nieprzewidywalnych, budzących niepokój i chaos (Jaskulska, 2013, s. 80). Victor Turner dostrzegał również w rytuałach nie tylko kulturę, niosącą za sobą repertuar symboli, stanowiących o wartościach danej zbiorowości, jak również źródło budowania struktury (Turner, 1987). Struktura zatem z jednej strony odpowiada za budowanie bezpieczeństwa poprzez właśnie przewidywalność, cykliczność, z drugiej strony świadczy o pewnej opresyjności (Mendel, 2007), która zakłada istnienie kogoś, kto dominuje, i kogoś, kto poddaje się zdominowaniu. Dziewczynka wraz z pozostałymi dziećmi automatycznie, nieświadomie dąży do wypełniania norm, (z)internalizuje je.

Rozdźwięk pomiędzy oficjalnymi wartościami głoszonymi przez szkołę a szkolną rzeczywistością odzwierciedla się w narracji dziewczynki w momencie opowiadania o obowiązujących w instytucji zasadach:

A znasz jakieś zasady, które panują w szkole? (K. KP):

No. To często ten A. się bije, a nie można się bić. Często też jak mamy jakieś ważne sprawy, to mówią nam - w szkole - jak coś się dzieje, to mamy to zgłaszać, a nie poza terenem szkoły [załatwiać - uzup. K. KP]. A po prostu mówię, jak ktoś jest to z uczniów, a pani nie mówi [nie reaguje - uzupeł. K. KP]. I też wiem, że nie biega się po schodach. Bo raz taki uczeń spadł ze schodów. Prawie spadł, ze schodów (...) I wtedy jak się on prawie przewrócił to się mnie oparł, no i ja wtedy ja byłam wtedy z J., a on się o nas oparł i my spadłyśmy na tę poręcz i nas tak brzuch bolał (...) I właśnie, to jest zasada, że on nie ma wcale krzywdy, a my mamy (D).

Z fragmentu wywiadu wynika, iż dziecko koncentruje się na zasadach/wartościach, które są wymagane, tworzone i oczekiwane przez instytucję wobec 
uczniów. W narracji dziewczynki sprowadzone są one do zakazów i nakazów, w których uczniowie nie mogą stosować agresji (zakaz bicia), biegać po schodach oraz są zobowiązywani do zgłaszania ważnych sytuacji, które dzieją się w szkole (nakaz informowania). Pojawia się zatem pytanie: jakimi zasadami/wartościami kieruje się kultura szkoły? Kogo obowiązują, kto je realizuje? Czy akceptowane formy zachowania odzwierciedlane w systemie zakazów i nakazów odnoszą się do zapewnienia bezpieczeństwa uczniów, skłonienia ich do posłuszeństwa, czy też są istotne wobec „wytworzenia nowej tożsamości” dziecka - ucznia? Przytaczane zasady mają charakter fasadowy - dziewczynka zwraca uwagę na częste łamanie normy o niestosowaniu agresji przez jednego z uczniów. Nie wszyscy stosują się zatem do narzuconych przez instytucję zasad - co więcej, okazuje się również, że szkoła staje się areną, na której ścierają się ze sobą kulturowe światy uczniów, nauczycieli, instytucji. Kultura szkoły w narracji dziewczynki powinna stać na straży dbania o bezpieczeństwo uczniów, ich prywatność (co jest obecne w jej biograficznym doświadczeniu) aktualnie natomiast jej udziałem jest obserwowanie, uczestniczenie i przeżywanie odmiennych wartości, sposobów postepowania dominującej kultury szkoły. Przestrzeganie przez dziecko zasad wytworzonych przez kulturę szkoły w odniesieniu do przekraczania norm przez agresywnego czy biegającego po schodach ucznia w jej ocenie staje się nieopłacalne: realizacja norm nie przynosi żadnego wzmocnienia, wprost przeciwnie. Dziewczynka, sama ulega konsekwencjom łamania zasad przez innych, sama je przestrzegając -,,(..) I właśnie, to jest zasada, że on nie ma wcale krzywdy, a my mamy” (D). Wygaszeniu, ukaraniu nie ulegają również sytuacje i zachowania uczniów występujących w opozycji do kulturowego świata szkoły. Pojawia się u dziecka wrażanie anomii, rozumianej przez E. Durkheima jako momentu utraty koherencji przez system normatywny, który finalnie zamienia się w chaos (Sztompka, 2004, s. 275). Zachwianie struktury, do której była przyzwyczajona i która pozwalała jej na poczucie stabilizacji powoduje, że w obliczu nierealizowania przez instytucję jej oczekiwań dąży do rozwiązywania problemów agresji za pomocą współpracy z innymi uczniami oraz akcentuje podziały my (klasa szkolna, pedagog) - oni (nauczyciele, dyrektor, agresywny uczeń). Kontynuując wątek wartości, jakimi kieruje się kultura szkoły, należy przyjrzeć się również wypowiedzi dziecka dotyczącej nakazu informowania o istotnych rzeczach dziejących się na terenie szkoły i rozwiązywaniu ich w wewnątrz instytucji. Pojawia się zatem pytanie, jakie sytuacje interesują świat szkoły i jaki jest cel informowania nauczycieli. W momencie kiedy dziecko powiadamia nauczyciela o wydarzeniu z uczniem, które w przeświadczeniu dziewczynki jest ważną sprawą, konfrontuje się z brakiem reakcji. Widoczna jest tutaj rozbieżność pomiędzy tym co jest istotne dla kultury 
dziecka, a tym, co ma znaczenie dla kultury szkoły. Dziewczynka na podstawie doświadczeń zdobywa wiedzę na temat tego, z kim może rozmawiać, na jakie tematy. Podjęcie rozmowy z wychowawczynią, w której dziecko ma poinformować o trudnym zachowaniu pani z języka polskiego, okazuje się niemożliwe:

\begin{abstract}
(...) Takich rzeczy to w ogóle. Jak pani potem mówi, że przesadzam to nie bardzo. Czuje, że tak było, będzie, bo stara wychowawczyni powiedziała, że przesadzam i nie mam skarżyć, a to naprawdę jest. Pani już nie wie [nie wie o sytuacji - uzupeł. K.KP], a powiedziała, że mamy [mówić - uzupeł. K. KP] (...) nasza pani jest z wuefu, no i musimy przychodzić na salę gimnastyczną no i potem inna pani wygania nas i nie możemy pani powiedzieć. A jak mamy wuef to no, pani nie chce, abyśmy tracili czas. Bo wtedy tracimy czas jak nic nie robimy i mamy mniej czasu. Tracimy czas na zabawę (D).
\end{abstract}

Okazuje się, że w kulturze szkoły są zagadnienia, informacje, których nie należy poruszać. Dziewczynka nie tylko nabywa wiedzę, o czym nie należy powiadamiać nauczycieli - ,nie rozmawia się o innych nauczycielach z nauczycielami”, ale też buduje przekonania dotyczące reakcji na bazie posiadanej wiedzy o poprzedniej wychowawczyni. Informowanie o trudnej, zagrażającej sytuacji, w której znajduje się dziecko (również w odniesieniu do problemu agresji w szkole) w rozumieniu nauczycieli sprowadza się do aktu skarżenia, który nie jest warty skonfrontowania i wyjaśnienia. Nie tylko treść rozmowy może być niewłaściwa, ale i jej czas - okazuje się bowiem, że istotniejszą kwestią dla kultury szkoły (kultury nauczyciela) jest realizowanie programu nauczania, który stanowi nadrzędny cel. Okazuje się, że nakaz informowania nie sprzyja bezpieczeństwu uczniów. Kontrolowany przepływ wiadomości nie służy rozwojowi dziecka, lecz sprawnemu zarządzaniu instytucją, wykonywaniu zadań, utrzymywaniu posłuszeństwa uczniów oraz ukazuje symboliczny obraz szkoły hermetycznej, posiadającej tematy tabu i problemy, które nie mogą wyjść poza jej mury.

Istotne w rozpatrywaniu obrazu szkoły są również przekonania dziecka odnoszące się do nauczycieli. W wypowiedziach dziewczynki, co można było zauważyć już w analizowanych fragmentach tekstu, zarysowuje się istnienie hierarchiczności i struktury społecznej. Przede wszystkim z narracji wyłania się dychotomiczny podział na nauczycieli i uczniów (w tym dziewczynkę) oraz „uczniów grzecznych i niegrzecznych”10. Przekonania na temat nauczycieli w narracji dziewczynki m.in. dotyczą charakteru wykonywanej pracy zawodowej:

10 Dychotomiczny podział na uczniów grzecznych i niegrzecznych powstał w wyniku kodowania 
No, bo wszyscy są w szkole, no tak biegają, po prostu nauczyciele mówią nie biegajcie, a po prostu nam się spieszy na lekcje (...). Nauczyciele to ciągle, albo gdzieś idą, bo po prostu mają inne lekcje, z klasami, i gadają ciągle. Każde inna pani, na każdej innej przerwie gada z panią wicedyrektor i potem my czekamy, pod klasą (D).

Z fragmentu wynika, iż rolą nauczyciela jest monitorowanie zachowań uczniów, kontrolowanie i przypominanie o zasadach panujących w szkole. Ich działalność w instytucji opisywana jest przez dziewczynkę za pomocą czynności, które są powtarzalne i zrutynizowane. Nauczyciele zostają przedstawieni przez aspekt wykonywanych działań - ciągle gdzieś idą, mają lekcje, ciągle gadają, gadają z panią wicedyrektor. Istotne jest tutaj zwrócenie uwagi dziecka na nauczycielu skupionym na rzeczowym wypełnianiu zadań - nie na nauczaniu, kontaktowaniu się z uczniem, wychowywaniu. Wzmocnienie koncentracji na realizacji norm kulturowych instytucji jest również widoczne w postrzeganiu uczniów przez pryzmat ich (nie)wypełniania. Nauczyciel nie jest zainteresowany ewentualnym powodem/celem łamania zasad przez uczniów, którzy w jednym czasie muszą realizować kulturowe normy instytucji i nauczyciela, co nie tylko powoduje pewien dysonans poznawczy u dziewczynki, ale i w tej sytuacji przynosi karę. Dziecko albo zostanie upomniane przez nauczyciela, albo się spóźni na zajęcia, próbując dokonać wyboru, który w jego przeświadczeniu będzie najmniej inwazyjny dla jego funkcjonowania w szkole.

Rozmowa z dziewczynką pozwoliła na uchwycenie kulturowego obrazu szkoły wraz z procesem przygotowania dziecka do wrastania w kulturę szkoły. Z dziecka poprzez wyposażenie go w tornister i narzucone odgórnie wzorce postępowania wobec instytucji i nauczycieli - szkoła tworzy ucznia. Dziecko jest socjalizowane poprzez zapoznanie się z normami i wzorcami zachowania kultury oficjalnej nabywa wiedzę dotyczącą wzorców zachowań (oczekiwanie na nauczyciela pod salą), zakazów oraz nakazów, oczekiwań, wartości. Dziecko wie, co należy/musi robić, co jest od niego oczekiwane, nie wie jednak, po co i dlaczego, do czego ma prawo. Wzrastanie dziecka w kulturę szkoły, które tutaj zaprezentowane jest jako socjalizowanie dziecka do roli ucznia, powoduje u dziewczynki zrodzenie się świadomości istnienia ograniczeń i zagrożeń. Wynikają one konfrontacji z przymusem (wobec norm), podtrzymywania agresji, kontrolowania, systemu zakazów

wywiadu narracyjnego dziecka. Kryterium podziału wiąże się z (nie)przyswojeniem wzorców postępowania, norm, wartości prezentowanych przez kulturę szkoły. Ze względu jednak na objętość artykułu zagadnienie nie zostanie poddane analizie. 
i nakazów niekonsekwentnie realizowanych oraz postrzegania przez szkołę ucznia jako wytworu działań instytucjonalnych, któremu zostaje odebrane prawo do decyzyjności i poczucia sprawstwa. W odniesieniu do zrekonstruowanego terminu totalnej kultury szkoły będzie w tym przypadku dotyczyć kształtowania dziecka jako ucznia, jego tożsamości, osobowości w kierunku podporządkowania się kultury instytucji, bez akcentowania jego świata kultury i podejmowania dialogu z biografią.

W kulturowym obrazie szkoły pojawiają się także aspekty stwarzające szanse wobec rozwoju dziecka. Dziewczynka upatruje je w przyznaniu prywatnej przestrzeni symbolicznie odzwierciedlającej się w szafce szkolnej, co stanowi bazę do uświadamiania, co dla niej stanowi wartość i jest tożsamościowo twórcze. Co prawda są one wynikiem indywidualnego wytwarzania znaczeń - kulturowe wzorce działania szkoły, normy, wartości, nie pozostają w świadomym dialogu z kulturą dziecka, który oznaczałby akcentowanie jego indywidualnego świata.

\section{DYSKUSJA ORAZ WNIOSKI}

Przedstawiony w narracji dziewczynki obraz szkoły jest pełen napięć i sprzeczności powstałych w wyniku stałego dialogu ze szkolnym światem. Kultura, z którą obcuje dziecko w szkole, czyli zespół wzorców postępowania, norm, wartości, założeń, przekonań, będzie wpływała na to, co zostanie u niego rozwinięte (Bruner, 2006, s. 235) na drodze socjalizacji i wychowania (Miller, 1981, s. 84-99, za: Kożyczkowska 2018) - czy szkoła będzie akcentowała kulturę (świat) ucznia czy koncentrowała się na realizacji własnej kultury. Kultura szkoły pojawiająca się w narracji dziewczynki zdaje się świadomie opierać na nośnikach kultury, które zmierzają do procesów „stwarzania ucznia”, nie uwzględniając jego repertuaru przeżyć, doświadczeń, wiedzy (aspektu psychologicznego) i nie wchodząc we wzajemny dyskurs. Taka teza pozwala ponownie spojrzeć na fragment narracji dziecka, które od momentu otrzymania prywatnego miejsca (szafki) - symbolicznie uzyskało prawo/pozwolenie do/na tworzenie własnego świata. Sytuacja ta, była na tyle ważna i potrzebna, iż w narracji dziecka stanowiła o chęci uczęszczania do szkoły.

Nieintencjonalne oraz rutynowe aspekty kultury szkoły wraz z kompetencjami dziecka stają się okazją wobec doświadczania szans w kierunku rozwoju tożsamości i osobowości. Stanowią jednak wynik tego, co konstruuje się na granicy pomiędzy światem szkoły a światem dziecka. Zwrócenie uwagi na kwestie kulturowe i ich związek z procesem wychowania i socjalizacją pozwalają zatem zobaczyć, jaki rodzaj podejmowanych działań przez szkołę jest (nie)istotny dla budowania 
indywidualnego świata dziecka, jakie czynniki mogą (nie) wpływać na jego motywy postępowania i (nie) rozwijać tożsamości i osobowości dziecka. Stanowią źródło wiedzy dotyczące procesu pełnego lub powierzchownego zaangażowania się w kulturę szkoły i wpływu na konstruowaną tożsamość i osobowość ucznia. Uwrażliwiają również na szanse i zagrożenia w odniesieniu do wytwarzanych przez ucznia znaczeń ze względu na jakość posiadanej „kulturowej skrzynki narzędziowej” (Bruner, 2006, s. 64) i (nie)podejmowanie dialogu kultury szkoły (w perspektywie instytucji i kultur poszczególnych nauczycieli) z indywidualnym światem ucznia.

\section{Bibliografia}

Augé, M. (2010). Nie-miejsca wprowadzenie do antropologii hipernowoczesności. Warszawa: PWN

Babicka-Wirkus, A. (2018). Respektowanie prawa do autoekspresji a rytuały oporu gimnazjalistów. Warszawa: Biblioteka Rzecznika Praw Dziecka.

Baranowska, A. (2008): Techniki adaptacji do życia w instytucji totalnej. Na przykładzie żołnierzy - mieszkańców obozu Babilon w Iraku. Toruń: Wydawnictwo Adam Marszałek.

Bruner, J.S. (2006). Kultura edukacji. Kraków: Wydawnictwo Universitas.

Bruner, J.S. (1987). Procesy reprezentacji w dzieciństwie. W: J.S. Bruner, Poza dostarczone informacje. Studia z psychologii poznawania. Warszawa: PWN.

Buliński, T. (2002). Człowiek do zrobienia. Jak kultura tworzy człowieka: studium antropologiczne. Poznań: Wydawnictwo Poznańskie.

Czarnecka, K., Zagółkowa, H. (1991). Słownik gwary uczniowskiej. Poznań: Kantor Wydawniczy SAWW.

Eller, J.D. (2012). Antropologia kulturowa. Globalne siły, lokalne światy. Kraków: Wydawnictwo Uniwersytetu Jagiellońskiego.

Filipiak, E. (2011). Z Wygotskim i Brunerem w tle: słownik pojęć kluczowych. Bydgoszcz: Wydawnictwo Uniwersytetu Kazimierza Wielkiego.

Foucault, M. (2009). Nadzorować i karać. Narodziny więzienia. Warszawa: Fundacja Aletheia.

Gibbs, A. (2015). Analizowanie danych jakościowych. Warszawa: PWN.

Goffman, E. (2011). Instytucje totalne. O pacjentach szpitali psychiatrycznych i mieszkańcach innych instytucji totalnych. Gdańsk: GWP.

Hofstede, G., Hofstede, G.J. (2007). Kultury i organizacje. Zaprogramowanie umysłu. Warszawa: Polskie Wydawnictwo Ekonomiczne.

Illich, I. (2010). Odszkolnić społeczeństwo. Warszawa: Biblioteka Myśli Współczesnej. James, A., Jenks, Ch., Prout, A. (1998). Theorizing childhood. Cambridge: Polity Press. Jaskulska, S. (2013): „Rytuał przejścia” jako kategoria analityczna. Przyczynek do dyskusji nad badaniem rytualnego oblicza rzeczywistości szkolnej. Studia Edukacyjne, 26, s. 79-97. 
Konecki, K. (2000). Studia z metodologii badań jakościowych. Teoria ugruntowana. Warszawa: PWN.

Kożyczkowska, A. (2018). Ja-świat: Romany Miller dialogowa i dialogiczna koncepcja socjalizacji i wychowania. W stronę osobowości zaangażowanej. Teraźniejszość-Człowiek-Edukacja, 2, s. 31-44.

Lee, N. (2001). Childhood and society. Grownig up in an age of uncertainty. Buckingham: Open University Press.

McLaren, P. (2015). Życie w szkołach. Wprowadzenie do pedagogiki krytycznej. Wrocław: Wydawnictwo Naukowe DSW.

Meighan, R. (1993). Socjologia edukacji. Toruń: Wydawnictwo Uniwersytetu Mikołaja Kopernika.

Mendel, M. (2007). Społeczeństwo i rytuał. Heterotopia bezdomności. Toruń: Wydawnictwo Adam Marszałek.

Miller, R. (1981). Socjalizacja, wychowanie, psychoterapia. Warszawa: PWN.

Nowicka, E. (2009). Świat człowieka - świat kultury. Warszawa: PWN.

Piwowarski, W. (1996). Socjologia religii. Lublin: Wydawnictwo KUL.

Sztompka, P. (2004). Socjologia. Analiza społeczeństwa. Kraków: Wydawnictwo „Znak”. Tuohy, D. (2002). Dusza szkoły. O tym, co sprzyja zmianie i rozwojowi. Warszawa: PWN. Turner, V.W. (1987). Betwixt and Between: the Liminal Period in Rites of Passage. W: L.C. Mahdi, S. Foster, M. Little (red.), Betwixt and Between. Patterns of Masculine and Feminine Initation. Illinois: Open Court Publishing.

Wagner, I. (2005). Stałość czy zmienność autorytetów. Kraków: Oficyna Wydawnicza „Impuls”.

Wróblewski M. (2014). Człowiek w przestrzeniach szkoły. Studium antropologiczne. Toruń: Wydawnictwo Naukowe UMK.

Wygotski, L.S. (1971). Wybrane prace psychologiczne. Warszawa: PWN. 